\title{
Regulation of Dopamine D1 Receptor Function by Physical Interaction with the NMDA Receptors
}

\author{
Lin Pei, ${ }^{1}$ Frank J. S. Lee, ${ }^{1}$ Anna Moszczynska, ${ }^{1}$ Brian Vukusic, ${ }^{1}$ and Fang Liu ${ }^{1,2,3,4}$ \\ ${ }^{1}$ Department of Neuroscience, Centre for Addiction and Mental Health, Clarke Division, Toronto, Ontario, M5T 1R8 Canada, and Departments of \\ ${ }^{2}$ Physiology and ${ }^{3}$ Psychiatry and ${ }^{4}$ Institute of Medical Science, University of Toronto, Toronto, Ontario, M5T 1R8 Canada
}

\begin{abstract}
Functional interactions between dopamine D1-like receptors and NMDA subtype glutamate receptors have been implicated in the maintenance of normal brain activity and neurological dysfunction. Although modulation of NMDA receptor functions by D1 receptor activation has been the subject of extensive investigation, little is known as to how the activation of NMDA receptors alters D1 function. Here we report that NMDA receptors regulate D1 receptor function via a direct protein-protein interaction mediated by the carboxyl tail regions of both receptors. In both cotransfected cells and cultured hippocampal neurons the activation of NMDA receptors increases the number of D1 receptors on the plasma membrane surface and enhances D1 receptor-mediated cAMP accumulation via a SNAREdependent mechanism. Furthermore, overexpression of mini-genes encoding either NR1 or D1 carboxyl tail fragments disrupts the D1-NR1 direct protein-protein interaction and abolishes NMDA-induced changes in both D1 cell surface expression and D1-mediated cAMP accumulation. Our results demonstrate that the D1-NR1 physical interaction enables NMDA receptors to increase plasma membrane insertion of D1 receptors and provides a novel mechanism by which the activation of NMDA receptors upregulates D1 receptor function. Understanding the molecular mechanisms by which D1 and NMDA receptors functionally interact may provide insight toward elucidating the molecular neurobiological mechanisms involved in many neuropsychiatric illnesses, such as schizophrenia.
\end{abstract}

Key words: dopamine receptors; NMDA receptors; protein-protein interactions; cAMP accumulation; receptor trafficking; G-proteins

\section{Introduction}

NMDA receptors and dopamine D1-like receptors represent two major structurally and functionally divergent families of neurotransmitter receptors in the CNS. The former is composed of a class of ligand-gated ion channels consisting of diverse subunits responsible for fast synaptic transmission. The latter belongs to the seven transmembrane domain receptor super-family exerting its biological effects primarily via the activation of adenylate cyclase by the G-protein signaling cascades. Numerous studies have shown that G-protein-coupled receptors regulate ligand-gated ion channel functions either by the activation of their intracellular signal transduction pathways (Greengard, 2001) or via direct protein-protein interactions (Liu et al., 2000; Lee et al., 2002). However, there have been few studies investigating the functional modulation of G-protein-coupled receptors by the activation of ligand-gated ion channels. Therefore, it is the subject of our present study to investigate whether the activation of NMDA

\footnotetext{
Received Aug. 23, 2003; revised Dec. 5, 2003; accepted Dec. 8, 2003.

This work was supported by the Canadian Institutes of Health Research (F.L.) and Canadian Psychiatric Research Foundation (F.L.). F.L. is a National Alliance for Research on Schizophrenia and Depression Young Investigator. We gratefully acknowledge Dr. Y.-T. Wang and Dr. M. P. Charlton for critical discussion and comments. We are thankful for the generous gift of the HA-D1 CDNA from Dr. M. Caron.

Correspondence should be addressed to Dr. Fang Liu, Department of Neuroscience, Centre for Addiction and Mental Health, Clarke Division, 250 College Street, Toronto, Ontario M5T 1R8 Canada. E-mail: f.liu.a@utoronto.ca or fang_liu@camh.net.

F. J. S. Lee's present address: Department of Neurology, Harvard Medical School, Children's Hospital, Boston, MA 02115.

DOI:10.1523/JNEUROSCI.3922-03.2004

Copyright $\odot 2004$ Society for Neuroscience $\quad 0270-6474 / 04 / 241149-10 \$ 15.00 / 0$
}

receptors is able to regulate dopamine D1 receptor-mediated functions and the potential molecular mechanism underlying this process.

NMDA receptors, activated by the principal excitatory neurotransmitter glutamate, are important in activity-dependent synaptic plasticity and excitotoxicity that underlie learning, memory, neural development, and many neurological disorders (Michaelis, 1998). NMDA receptors, which mediate cation flux, exist as heteromeric assemblies of multiple subunits including NR1 and NR2 subunits (Michaelis, 1998). The NR1 subunit mRNA is spliced alternatively at three exons to form eight splice variants, which results in the presence/absence of $\mathrm{C} 1, \mathrm{C} 2$, or both cassettes at the C terminus (Ziff, 1997; Guilarte and McGlothan, 2003). NR2 subunits are encoded by four different gene products (NR2A, B, C, and D) (Durand et al., 1992; Sugihara et al., 1992; Hollmann et al., 1993; Hollmann and Heinemann, 1994).

Dopamine D1-like receptors, which include the D1 and D5 receptors, play a major role in regulating neuronal motor control, cognition, event prediction, and emotion (Missale et al., 1998; Goldman-Rakic, 1999). D1 and D5 receptors preferentially couple to Gs proteins, stimulating the activity of adenylate cyclase and protein kinase A-dependent (PKA) pathways. Previous studies have shown the functional interaction between D1-like receptors and NMDA receptors. Activation of D1 receptors enhances the NMDA currents via a PKA-dependent pathway that most likely involves the phosphorylation and activation of DARPP-32 (Greengard, 2001). Similar results are demonstrable on the EPSC of the pharmacologically isolated NMDA receptor-mediated 
component of synaptic transmission (Cepeda et al., 1992; Colwell and Levine, 1995). In the hippocampus, dopamine has been shown to produce a synapse-specific enhancement of long-term potentiation (LTP) via D1/D5 receptors and cAMP (Huang and Kandel, 1995). Furthermore, we have obtained evidence that D1 receptors can inhibit NMDA receptor currents and NMDA receptor-mediated excitotoxicity via direct protein-protein interactions (Lee et al., 2002). Similarly, a recent report has confirmed the direct interaction between D1 and NMDA receptors via the use of bioluminescence resonance energy transfer in cotransfected COS-7 cells (Fiorentini et al., 2003). In addition, several studies have suggested that NMDA receptors may modulate D1-mediated functions, because blockade of NMDA receptor activity led to attenuation of the ability of D1 in the modulation of neuronal activity (Huang et al., 1998) and in the induction of immediate early gene expression (Konradi et al., 1996; Keefe and Ganguly, 1998). A recent study also suggests that the activation of NMDA receptors recruits D1 receptors to the cell plasma membrane and enhances D1-mediated cAMP accumulation (Scott et al., 2002). Despite the above observation the mechanisms that enable NMDA receptors to modulate D1-mediated functions remain mostly unclear.

\section{Materials and Methods}

cAMP accumulation assay. COS-7 cells were transiently transfected with the indicated cDNA constructs by electroporation ( $40 \mu \mathrm{g}$ of each indicated cDNA per $2.5 \times 10^{7}$ cells; $48 \Omega, 135 \mathrm{~mA}, 500 \mathrm{mF}$ ), placed in 24 -well plates, and grown for $4-5 \mathrm{~d}$. Cells were washed with $0.5 \mathrm{ml}$ of prewarmed Dulbecco's $\alpha$-MEM containing 1-methyl-3-isobutylxanthine and $1 \mu \mathrm{M}$ propranolol and then were incubated in the above medium in the presence or absence of antagonist/agonist for the indicated time period at $37^{\circ} \mathrm{C}$ and $5 \% \mathrm{CO}_{2}$. The reaction was terminated by the addition of $0.5 \mathrm{ml}$ of $0.2 \mathrm{~N} \mathrm{HCl}$ and incubation for $20 \mathrm{~min}$ at $4^{\circ} \mathrm{C}$. Cellular debris was pelleted, and aliquots of the supernatant were used to determine the cAMP content via immunodetection (Amersham Biosciences, Oakville, Ontario, Canada) as described previously (Liu et al., 1995). To ensure equivalence of whole-cell cAMP assay comparisons, we monitored receptor densities for $\left[{ }^{3} \mathrm{H}\right] \mathrm{SCH}-23390$ binding (3.0 nM final concentration).

Primary cultures from hippocampus were prepared from fetal Wistar rats (embryonic day 17-19) and placed on 24-well plates for 10-14 d as previously described (Liu et al., 2000). cAMP assay with the use of primary culture neurons was performed identically as with COS-7 cells.

Ligand binding assay. COS-7 cells were transiently transfected as described above, placed into $150 \mathrm{~mm}$ plates, and cultured for $4-5 \mathrm{~d}$. COS-7 cells were maintained in Dulbecco's $\alpha$-MEM supplemented with $10 \%$ fetal calf serum at $37^{\circ} \mathrm{C}$ and $5 \% \mathrm{CO}_{2}$. Next the cells were collected, and membranes were prepared for binding assays as described previously (Liu et al., 1995). For saturation experiments $0.5 \mathrm{ml}$ aliquots of tissue homogenate $(\sim 50-100 \mu \mathrm{g}$ of membrane protein) were incubated in duplicate with increasing concentrations of $\left[{ }^{3} \mathrm{H}\right] \mathrm{SCH}-23390(85.5 \mathrm{Ci} /$ $\mathrm{mmol}$; $30-6800 \mathrm{pm}$ final concentration) for $120 \mathrm{~min}$ at room temperature in a total volume of $1.5 \mathrm{ml}$. For competition binding studies $0.5 \mathrm{ml}$ of membranes was incubated in duplicate with $\left[{ }^{3} \mathrm{H}\right] \mathrm{SCH}-23390(250-400$ $\mathrm{pM})$ and increasing concentrations of competing ligands $\left(10^{-13}\right.$ to $10^{-4}$ M) for $120 \mathrm{~min}$. Experiments were terminated by rapid filtration, and filters were monitored for tritium. Nonspecific binding was defined in the presence of $10 \mu \mathrm{M}(+)$-butaclamol. Binding data were analyzed by the nonlinear least-square curve-fitting program KaleidaGraph (Abelbeck Software, Synergy, Reading, PA) as described previously (Liu et al., 1995).

Confocal imaging. Human embryonic kidney-293 (HEK-293) cells were transiently transfected with the indicated cDNA constructs via the Lipofectamine method $\left(6-10 \mu \mathrm{g}\right.$ of each indicated cDNA per $7.5 \times 10^{6}$ cells), placed in $35 \mathrm{~mm}$ plates, and grown for $2-4 \mathrm{~d}$. For preblocking immunostaining the cells first were incubated with the monoclonal antihemagglutinin (anti-HA) antibody (10 $\mu \mathrm{g} / \mathrm{ml}$; Babco, Berkeley, CA) for $45 \mathrm{~min}$ and then a cold (nonconjugated) secondary antibody $(10 \mu \mathrm{g} / \mathrm{ml}$; Sigma, St. Louis, MO) for another $45 \mathrm{~min}$ at $4^{\circ} \mathrm{C}$. After treatment with
$500 \mu \mathrm{M}$ NMDA/10 $\mu \mathrm{M}$ glycine or extracellular solution [ECS; (containing in mM): $25 \mathrm{HEPES}, 140 \mathrm{NaCl}, 1.3 \mathrm{CaCl}_{2}, 33$ D-glucose, 0.003 glycine, and $5.4 \mathrm{KCl}$, pH 7.35; osmolarity, 310-320 mOsm] for $30 \mathrm{sec}$ at room temperature, the cells were fixed for $20 \mathrm{~min}$ at room temperature with $4 \%$ paraformaldehyde in PBS and stained with the same anti-HA primary antibody and Cy3-conjugated anti-mouse secondary antibody to detect the newly inserted HA-D1 receptors on the plasma membrane under nonpermeabilized conditions. The HLA (human leukocyte antigen) class I antigen then was stained with the FITC-conjugated monoclonal antiHLA antibody (Sigma) under permeabilized conditions (cells were permeabilized by using PBS/0.1\% Triton X-100 for $10 \mathrm{~min}$ ). Optical images were collected by confocal scanning with dual channels for Cy3 and FITC fluorescence with a Zeiss 100 confocal microscope (Oberkochen, Germany) with a $100 \times$ oil objective lens. To ensure that the detection levels for the red (Cy3) and green (FITC) channels were consistent between experiments (control/treatment), we initially scanned randomly acquired fields (typically four to six) from each coverslip/experimental condition and then had the intensity levels adjusted to a minimum of $150 \%$ over background values for each color detector ("thresholding" pixel intensities 1.5 times above detected background values were considered to be representative of specific receptors). Under these conditions no detectable bleedthrough from one channel was observed. Detector and intensity levels were matched for each particular coverslip; settings were maintained throughout the coverslip. The same ratios determined between background/staining intensity were used to compare between control and NMDA-treated cells.

Cell-ELISA assays. Cell-ELISA assays (colorimetric assays) were done essentially as previously described (Lee et al., 2002). HEK-293 cells were transiently transfected with the indicated cDNA constructs by the Lipofectamine method $\left(6-10 \mu \mathrm{g}\right.$ of each indicated cDNA per $7.5 \times 10^{6}$ cells), distributed equally to two six-well plates $(35 \mathrm{~mm} /$ well), and grown for $2-4 \mathrm{~d}$. The same density of cotransfected cells was treated with $500 \mu \mathrm{M}$ NMDA/10 $\mu \mathrm{M}$ glycine or ECS before being fixed in $4 \%$ paraformaldehyde for $10 \mathrm{~min}$ in the absence (nonpermeabilized conditions) or the presence (permeabilized conditions) of $1 \%$ Triton X-100. Cells were incubated with a monoclonal antibody against the HA epitope (Babco, Richmond, CA; $1 \mu \mathrm{g} / \mathrm{ml}$ to detect the HA epitope inserted into the extracellular $\mathrm{N}$ terminus of $\mathrm{D} 1$ receptors) for the purpose of labeling the receptors on the cell surface under nonpermeabilized conditions or the entire receptor pool under permeabilized conditions. After an incubation with the corresponding horseradish peroxidase (HRP)-conjugated secondary antibodies (Sigma), the HRP substrate $o$-phenylenediamine (OPD; Sigma) was added to produce a color reaction that was stopped with $3 \mathrm{~N} \mathrm{HCl}$. The cell surface expression of HA-D1 after pretreatment with NMDA was presented as the ratio of colorimetric readings under nonpermeabilized conditions to those under permeabilized conditions and then normalized to their respective control groups (pretreated with ECS). Analysis was done by using at least 12 separate dishes in each group. Cell-ELISA assays that used primary hippocampal neurons were performed identically with assays that used HEK-293 cells, with the exception that anti-D1 antibody (Chemicon, Temecula, CA) instead of anti-HA was used as the primary antibody.

Primary cultures, recombinant adenovirus construction, and infection. Primary cultures from hippocampus were prepared from fetal Wistar rats (embryonic day 17-19) on Cell ${ }^{+}$(Sarstedt, N $\int$ mbrecht, Germany) culture dishes for $14 \mathrm{~d}$ as previously described (Liu et al., 2000). Recombinant adenoviruses were formed by cotransfecting cDNAs encoding the D1-t2, D1-t3 in the shuttle vector pDC315 (Microbix Biosystems, Toronto, Ontario, Canada) with replication-deficient adenovirus type 5 DNA into HEK-293 cells. The recombinant adenoviruses containing the D1- $\mathrm{t} 2, \mathrm{D} 1-\mathrm{t} 3 \mathrm{cDNAs}$ were isolated, confirmed by restriction analysis, plaque-purified, expanded, and titered. For infection the primary hippocampal cultures were infected with 10 to $\sim 20$ plaque-forming units per neuron [multiplicity of infection (moi)] of recombinant adenovirus in $500 \mu \mathrm{l}$ of culture medium. Cultures were supplemented with $1.5 \mathrm{ml}$ of fresh medium $1 \mathrm{hr}$ after infection and were analyzed 12-24 hr after infection (Lee et al., 2002).

GST fusion proteins and mini-genes. Dopamine $\mathrm{D} 1_{\mathrm{CT}}, \mathrm{D} 1-\mathrm{t} 1, \mathrm{D} 1-\mathrm{t} 2$, D1-t3, NR1-1a $\mathrm{a}_{\mathrm{CT}}$, NR1-C0, NR1-C1, NR1-C2, and NR2A $\mathrm{CT}_{\mathrm{cDNA}}$ 


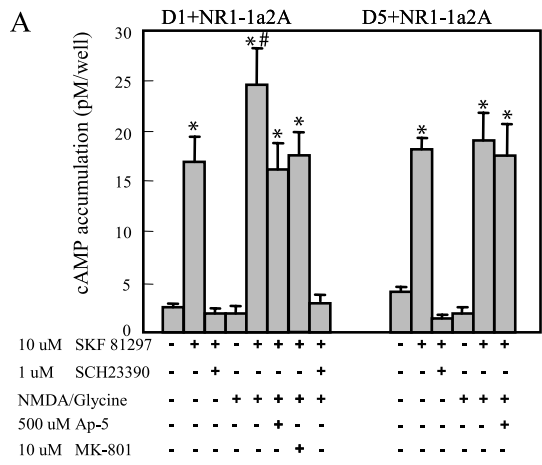

C

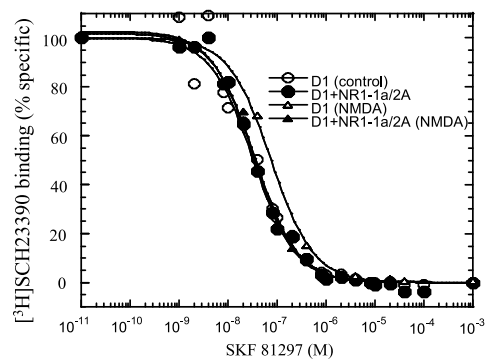

D

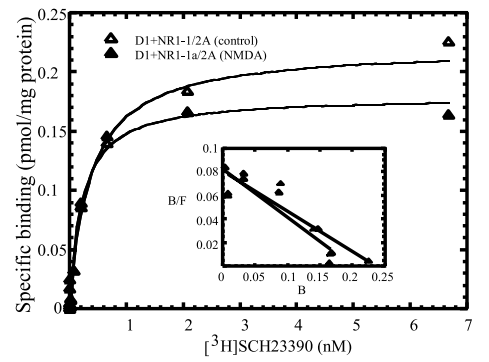

Figure 1. NMDA receptors modulate D1, but not D5, receptor-mediated cAMP accumulation in COS-7 cells coexpressing both receptors. $A$, NMDA receptor stimulation (500 $\mu \mathrm{m}$ NMDA/10 $\mu \mathrm{m}$ glycine; 30 sec at room temperature) enhanced D1-mediated, but not D5-mediated, CAMP accumulation by 45\%, an effect that could be blocked by the selective D1-like receptor antagonist SCH-23390 or the NMDA receptor antagonist AP5 or MK-801, respectively. Data are representative as the means \pm SEM of 12 independent experiments. Data were analyzed by ANOVA, followed by post hoc Student-Newman-Keuls test. *Significantly different from control group ( $p<0.05)$; " significantly different from SKF treatment group $(p<0.05)$. $B$, NMDA receptor stimulation increases the efficacy, but not affinity, of D1 receptor-mediated cAMP accumulation. Estimated $\mathrm{EC}_{50}$ values are listed in Results. C, The affinity of SKF-81297 for D1 receptors is unchanged after NMDA treatment both in cells expressing D1 only and cells coexpressing D1 with NMDA receptors, as indexed by [ ${ }^{3} \mathrm{H}$ ] SCH-23390 binding. $K_{\mathrm{i}}$ values are listed in Results. The graph is a representative plot of four independent experiments. D, NMDA pretreatment did not alter the estimated $K_{\mathrm{D}}$ or $B_{\max }$ of $\left[{ }^{3} \mathrm{H}\right.$ ] SCH-23390 binding cells coexpressing D1 with NMDA receptors. The graph is a representative plot of three independent experiments.

encoding fragments were amplified by PCR from full-length cDNA clones. All 5' and $3^{\prime}$ oligonucleotides incorporated BamHI and EcoRI sites, respectively, to facilitate subcloning into pcDNA3 or pGEX4T-2. Initiation methionine residues and stop codons also were incorporated where appropriate. GST-fusion proteins were prepared from bacterial lysates as described by the manufacturer (Amersham Biosciences). To confirm appropriate splice fusion and the absence of spurious PCRgenerated nucleotide errors, we resequenced all constructs.

Coimmunoprecipitation, protein affinity purification (pull-down), and Western blotting. Coimmunoprecipitation, affinity pull-down, and Western blot analyses were performed as previously described (Liu et al., 2000; Lee et al., 2002). Rat brain hippocampus (100 mg) or transfected COS-7 cells $\left(\sim 2 \times 10^{7}\right)$ were homogenized in buffer containing (in $\mathrm{mm}$ ) 50 Tris-Cl, pH 7.6, $150 \mathrm{NaCl}, 2$ EDTA, 1 PMSF plus 1\% Igepal CA-630, 0.5 to $\sim 1 \%$ sodium deoxycholate, $1 \%$ Triton X-100, and protease inhibitor mixture ( $5 \mu \mathrm{l} / 100 \mathrm{mg}$ of tissue; Sigma); after being centrifuged at $10,000 \times g$ at $4^{\circ} \mathrm{C}$ for $20 \mathrm{~min}$, the supernatant was extracted and protein concentrations were measured (Pierce, Rockford, IL). For coimmunoprecipitation experiments, solubilized hippocampal/cell extracts (500 to $\sim 700 \mu$ g of protein) were incubated in the presence of primary antibodies anti-NR1 (Pharmingen, San Diego, CA), anti-D1 (Chemicon), or mouse IgG $\left(1\right.$ to $\sim 2 \mu \mathrm{g}$ ) for $4 \mathrm{hr}$ at $4^{\circ} \mathrm{C}$, followed by the addition of $20 \mu \mathrm{l}$ of protein A/G agarose (Santa Cruz Biotechnology, Santa Cruz, CA) for $12 \mathrm{hr}$. Pellets were washed four times in the buffer described above, boiled for $5 \mathrm{~min}$ in SDS sample buffer, and subjected to SDS-PAGE. In each experiment 20 to $\sim 50 \mu \mathrm{g}$ of tissue-extracted protein was used as control. For affinity purification experiments the solubilized hippocampal extracts (50-100 $\mu \mathrm{g}$ of protein) were incubated with glutathioneSepharose beads (Pharmacia, Dorval, Québec, Canada) bound to the indicated GST-fusion proteins ( 50 to $\sim 100 \mu \mathrm{g}$ ) at room temperature for $1 \mathrm{hr}$. Beads were washed three times with $600 \mu \mathrm{l}$ of PBS containing
$0.1-0.5 \%$ Triton X-100 before the bound proteins were eluted with glutathione elution buffer. Elutes were incubated in sample buffer and subjected to $10 \%$ SDS-PAGE for Western blot analysis. Blots were blocked with $5 \%$ nonfat dried milk dissolved in TBST buffer $(10 \mathrm{~mm}$ Tris, $150 \mathrm{~mm} \mathrm{NaCl}$, and $0.1 \%$ Tween-20) for 1 $\mathrm{hr}$ at room temperature, washed three times with TBST buffer, and then incubated with the appropriate primary antibody (anti-D1, antiD5, or anti-NR1, diluted in 1\% milk in TBST) overnight at $4^{\circ} \mathrm{C}$ and washed again with TBST buffer three times; the membrane was incubated with horseradish peroxidase-conjugated secondary antibody (diluted in $1 \%$ milk in TBST; Sigma) for $1.5 \mathrm{hr}$ at room temperature. The proteins were visualized with enhanced chemiluminescence reagents as described (Amersham Biosciences).

In vitro binding assays. Glutathione beads carrying GST fusion proteins (D1-t2, D1-t3) or GST (10 to $\sim 20 \mu \mathrm{g}$ each) alone were incubated with $\left[{ }^{35} \mathrm{~S}\right]$-methionine-labeled NR1-C0, NR1$\mathrm{C} 1$, or NR1-C2 probe, respectively. Then the beads were washed six times with PBS containing $0.5 \%$ Triton X-100 and eluted with $10 \mathrm{~mm}$ glutathione elution buffer. Eluates were separated by SDS-PAGE and visualized by autoradiography.

\section{Results}

Activation of NMDA receptor increases dopamine D1 receptor-mediated cAMP accumulation in cotransfected cells

As the first step toward investigating whether the activation of NMDA receptors will modulate D1 receptor function, we tested the effects of NMDA receptor activation on D1 receptor-mediated cAMP accumulation in COS-7 cells coexpressing D1 and NMDA receptors. As depicted in Figure $1 A$, left, the selective D1-like receptor agonist SKF-81297 (10 $\mu \mathrm{M}$ for $15 \mathrm{~min}$ at $\left.37^{\circ} \mathrm{C}\right)$ stimulated D1mediated cAMP accumulation, an effect that was blocked by the selective D1-like receptor antagonist SCH-23390 ( $1 \mu \mathrm{M}$ for 15 $\min$ at $37^{\circ} \mathrm{C}$ ). Interestingly, when the cotransfected cells were pretreated with $500 \mu \mathrm{M}$ NMDA/10 $\mu \mathrm{M}$ glycine for $30 \mathrm{sec}$, the SKF-stimulated adenylate cyclase activity was increased by $\sim 45 \%$ $(n=12 ; p<0.05)$. The fact that NMDA failed to modulate D1-mediated cAMP accumulation in cells expressing D1 receptor alone (data not shown) and that both AP-5 and MK801 could block the NMDA/glycine-induced effect on D1-mediated function addresses the requirement for the activation of NMDA receptors and calcium influx. To confirm that the observed cAMP activity enhancement actually is mediated by D1 receptors, we pretreated cotransfected cells with SCH-23390 and observed that the NMDA receptor activation-induced cAMP enhancement was abolished by the application of SCH-23390, strongly suggesting that the enhanced cAMP accumulation was mediated by D1 receptors. Furthermore, the activation of NMDA receptors showed no effects on D5-mediated cAMP accumulation in COS-7 cells expressing both D5 and NMDA receptors (Fig. $1 A$, right), although dopamine D1 and D5 receptors share similar pharmacological profiles and strong amino acid homology. We also observed that, in cells coexpressing D1 and NMDA receptors, the estimated $\mathrm{EC}_{50}$ for D1-stimulated cAMP production in NMDApretreated cells ( $312 \pm 56 \mathrm{nM} ; n=3$ ) is virtually identical to that 
for untreated control cells $(307 \pm 71 \mathrm{nM}$; $n=3$ ) despite the enhancement in apparent maximal accumulation of cAMP levels (Fig. $1 B$ ). Thus the enhancement of D1mediated cAMP production cannot be attributed to NMDA-induced competitive increase of D1 receptor agonist efficacy. Furthermore, the affinity for SKF-81297 to compete with $\left[{ }^{3} \mathrm{H}\right] \mathrm{SCH}-23390$ binding at D1 receptors in cells coexpressing D1 and NMDA receptors after NMDA pretreatment $\left(K_{\mathrm{i}}=33 \pm 3 \mathrm{nM} ; n=4\right)$ was not significantly different from that for untreated cells $\left(K_{\mathrm{i}}=30 \pm 1 \mathrm{nM} ; n=4\right)$ or cells expressing D1 receptors alone $\left(K_{\mathrm{i}}=\right.$ $35 \pm 6 \mathrm{~nm} ; n=4$ ) (Fig. 1C). NMDA pretreatment did not modify significantly either the estimated $K_{\mathrm{D}}$ (untreated control, $360 \pm 70 \mathrm{pM}$; NMDA-treated, $220 \pm 40$ pM; $n=3$ ) or $B_{\max }$ (untreated control, $0.22 \pm 0.04 \mathrm{pmol} / \mathrm{mg}$ protein; NMDAtreated, $0.18 \pm 0.03 \mathrm{pmol} / \mathrm{mg}$ protein; $n=$ 3) for $\left[{ }^{3} \mathrm{H}\right] \mathrm{SCH}-23390(0.03-6.8 \mathrm{nM} ; 85$ $\mathrm{Ci} / \mathrm{mmol}$ ) binding to $\mathrm{D} 1$ receptors in cells coexpressing D1 with NMDA receptors (Fig. $1 D$ ). Some of the data points in Figure $1 D$ are compressed on the bottom of the curve; despite the scatter in the Scatchard plots (Fig. $1 D$, inset) the affinity is not significantly different between control and NMDA-treated samples (360 vs 220 $\mathrm{pm})$. Analyses via both nonlinear regression and Scatchard plot transformation (data not shown) resulted in virtually identical outcomes, strongly indicating that these results are robust. In addition, the competition binding studies also strongly suggest that ligand-binding affinity is not altered with NMDA treatment. Taken together, these data suggest that the activation of NMDA receptors enhances D1 receptor-mediated cAMP accumulation without altering the pharmacological properties or the expression level of D1 receptors.

\section{NMDA receptor activation increases D1} receptor-mediated cAMP accumulation via an interaction with the carboxyl tail of the D1 receptor

Given that (1) NMDA receptor activation increased D1, but not D5-mediated cAMP accumulation; (2) D1 and D5 receptors display particular sequence divergence within the $\mathrm{C}$ terminus (CT), a region that might confer subtype-selective functional attributes and coupling to distinct effectors independent of those classically associated with G-protein activation; and (3) that NMDA receptors can couple directly to the CT of the D1, but not D5, receptor (Lee et al., 2002), we investigated whether the $\mathrm{D} 1$ receptor $\mathrm{CT}$ is responsible for the
A

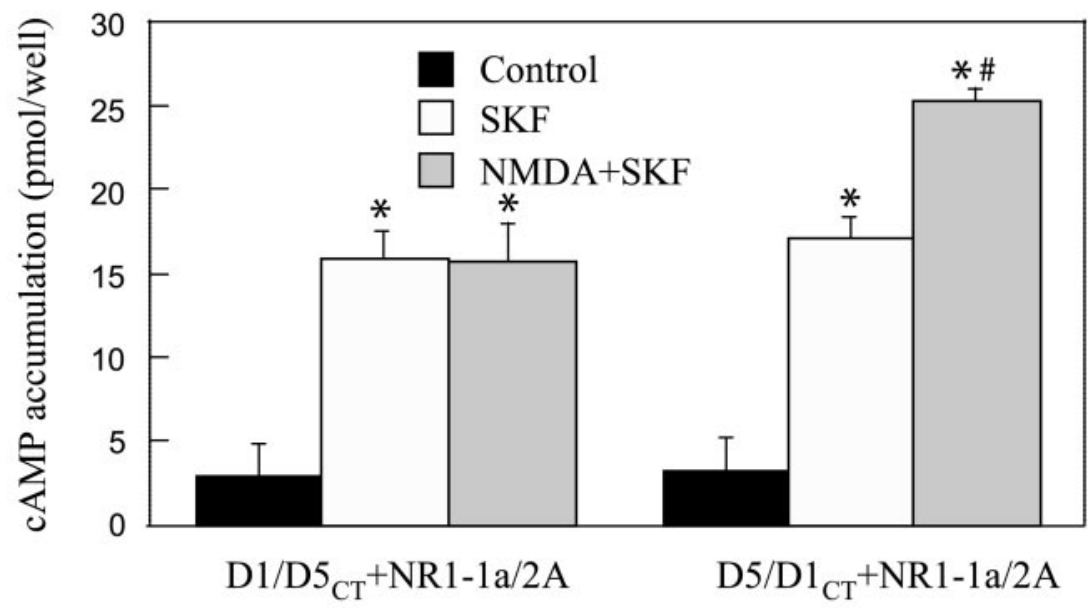

$\mathrm{B}$

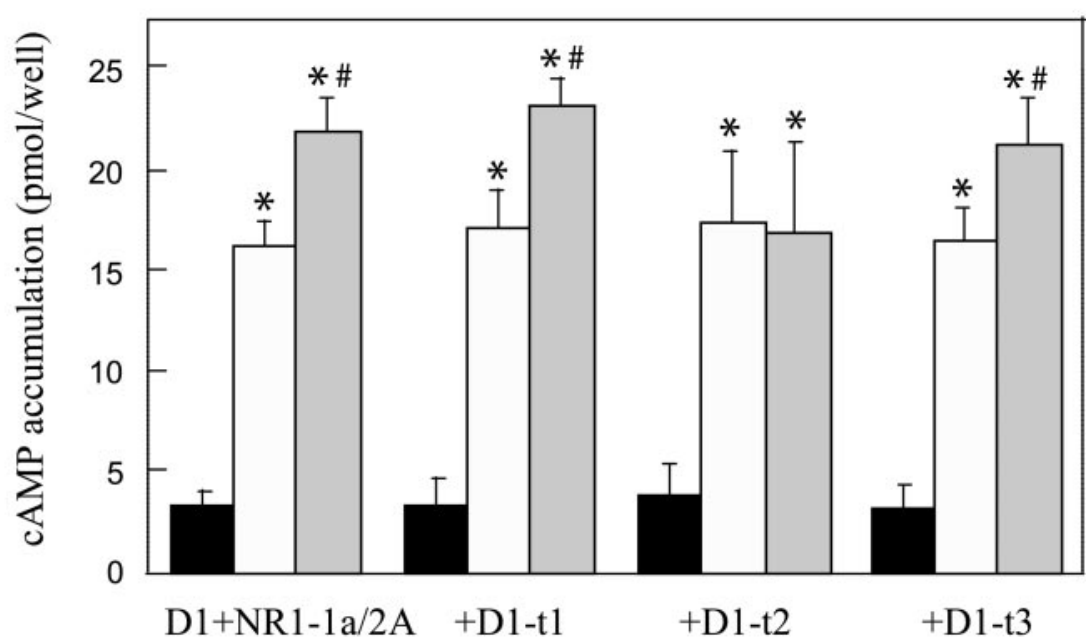

$\mathrm{C}$

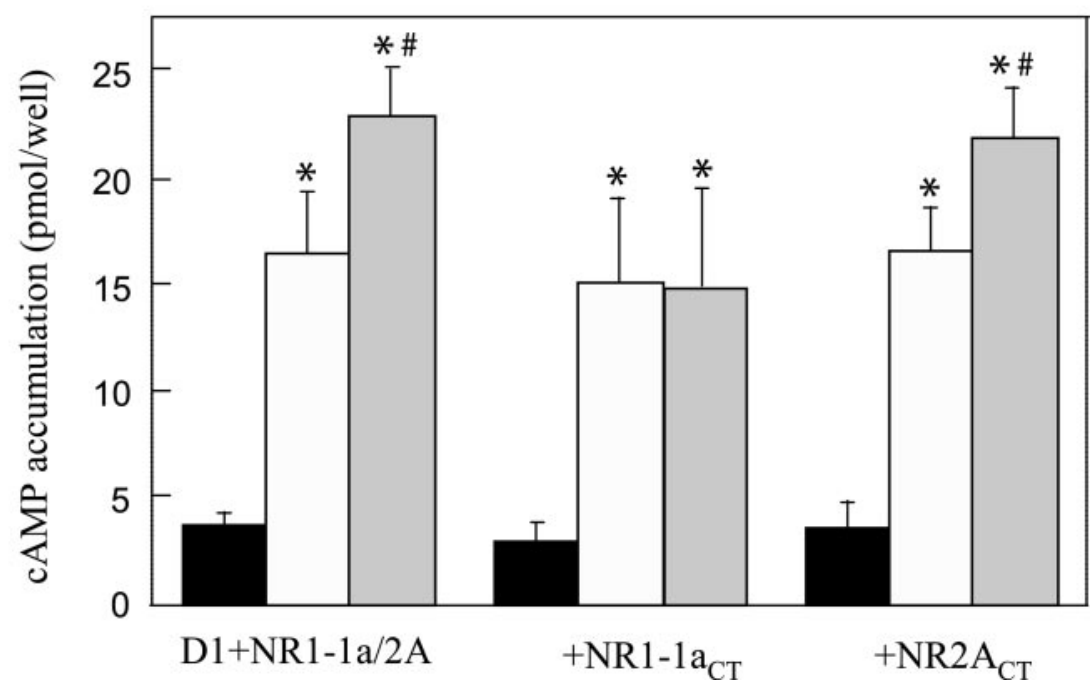

Figure 2. NMDA receptor modulation of D1 CAMP production is dependent on D1-CT and NR1-1a-CT sequences in cells cotransfected with D1/NMDA receptors. $A$, Chimeric D1 receptors in which the carboxyl tail was swapped with sequences encoded by D5-CT (D1/D5$\left(\mathrm{C}_{360-477}\right)$ are unresponsive to NMDA receptor stimulation, whereas D5/D1-CT ${ }_{332-446}$ receptor mutants fully reconstitute NMDA receptor-mediated increases in cAMP activity. $B$, The ability of the NMDA receptors to enhance D1 receptor-mediated cAMP accumulation functionally was abolished by coexpressing with a mini-gene encoding the D1-t2 domain, but not the D1-t1 or D1-t3 domains. C, The ability of the NMDA receptors to enhance D1 receptor-mediated cAMP accumulation functionally was abolished by coexpressing with a mini-gene encoding the NR1-1a-CT domain, but not the NR2A-CT domain. Data are representative as the means \pm SEM of 6-10 independent experiments. Data were analyzed by ANOVA, followed by post hoc Student-Newman-Keuls test. *Significantly different from control group ( $p<0.05)$; ${ }^{\#}$ significantly different from SKF treatment group $(p<0.05)$. 
A
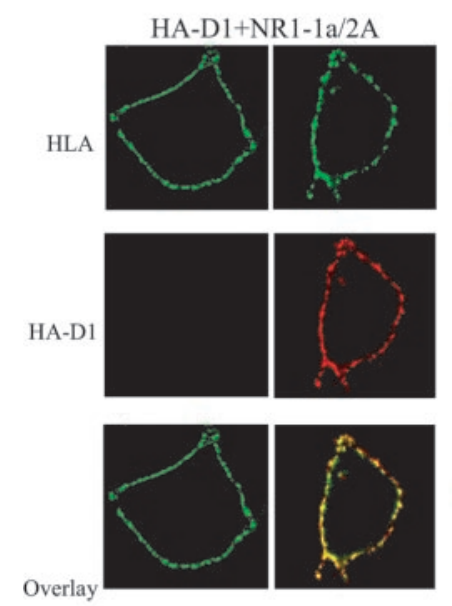

Control

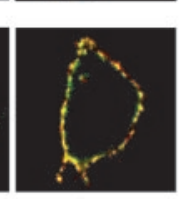

NMDA/glycine
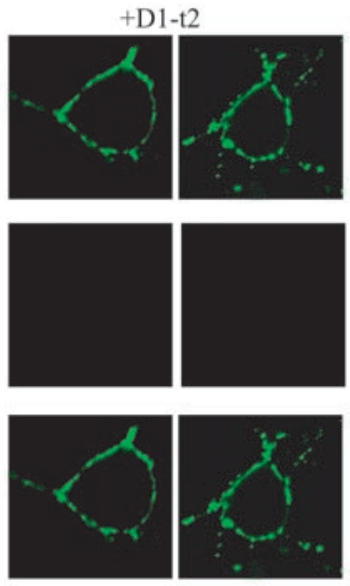

Control

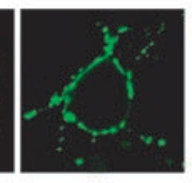

NMDA/glycine
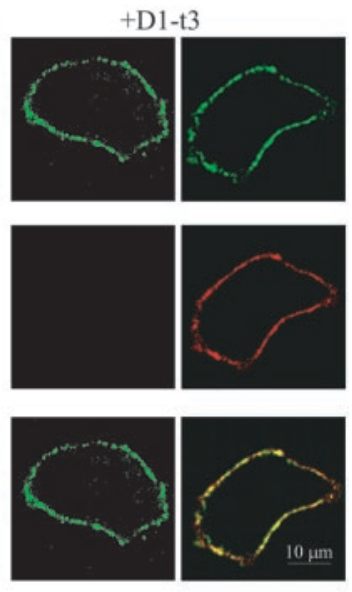

Control

NMDA/glycine

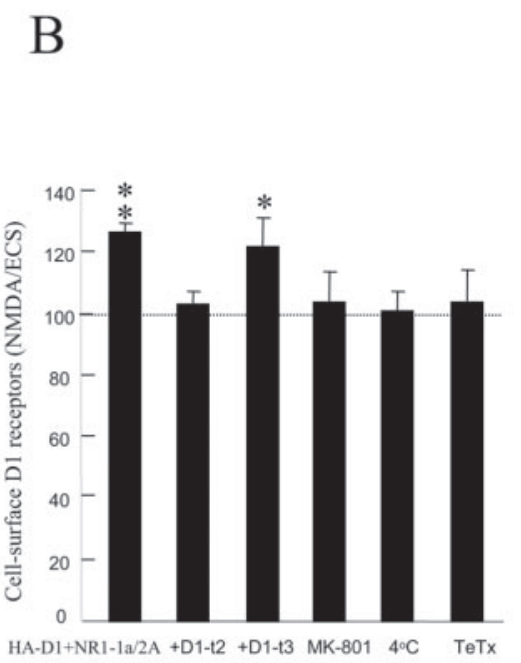

ceptor is required for the expression of the functional modulation of D1 by NMDA receptors.

To confirm these results and to delineate the region(s) of the D1 receptor CT involved in the functional interaction with the NMDA receptors, we used three D1-CT mini-genes $\left[\mathrm{A}_{357}-\mathrm{N}_{386}\right.$ (D1-t1), $\mathrm{L}_{387}-\mathrm{L}_{416}$ (D1-t2), $\mathrm{S}_{417}-\mathrm{T}_{446}$ (D1-t3)], of which D1-t2 and D1-t3 have been shown previously to be critical for direct binding to NR1-1a and NR2A subunits, respectively (Lee et al., 2002). As shown in Figure $2 B$, cAMP assays revealed that overexpression of the mini-gene encoding D1-t2, but not D1-t1 or D1-t3, was able to abolish completely the ability of NMDA receptor to modulate D1 receptor-mediated cAMP accumulation functionally. In addition, overexpression of a mini-gene encoding the NR1-1a CT (NR1-1a $\left.\mathrm{C}_{\mathrm{CT}}\right)$, but not NR2A CT $\left(\mathrm{NR}^{2} \mathrm{~A}_{\mathrm{CT}}\right)$, significantly blocked the NMDA-induced D1-mediated cAMP enhancement (Fig. 2C). These data indicate the absolute requirements of the D1-t2 motif and the possible involvement of the D1-t2: NR1-1a direct interaction in this process.

\section{Activation of NMDA receptor enhances} D1 receptor membrane expression Changes in G-protein-coupled receptor distribution by altering receptor trafficking/internalization/desensitization long have been identified as a means by which receptor functions are modulated (Claing et al., 2002). Therefore, we subsequently examined whether the observed enhancement of D1 receptor-mediated cAMP accumulation by the activation of NMDA receptors is a consequence of increased D1 receptor cell surface expression. Because increased cell surface receptor expression might arise from enhanced membrane insertion or, alternatively, by affecting the rate of receptor internalization, we used an immunocytochemistry-based method that allows for specific visualization of newly inserted receptors (Lu et al., 2001). Thus in HEK-293 cells coexpressing NMDA and HA-D1 receptors (HA epitope is inserted into the extracellular $\mathrm{N}$ terminus of the $\mathrm{D} 1$ receptor), the preexisting cell surface HA-D1 receptors first were blocked with anti-HA primary antibody and a nonfluorescence-conjugated secondary observed NMDA receptor modulation of D1-mediated cAMP accumulation by using chimeric $\mathrm{D} 1$ and $\mathrm{D} 5$ receptors $\left(\mathrm{D} 1 / \mathrm{D} 5_{\mathrm{CT}}\right.$, $\mathrm{D} 5 / \mathrm{D} 1_{\mathrm{CT}}$ ) in which the CTs were swapped (Demchyshyn et al., 2000). As illustrated in Figure $2 A, D 5 / D 1_{C T}$ fully reconstituted the ability of NMDA receptor activation to enhance $\mathrm{D} 5 / \mathrm{D} 1_{\mathrm{CT}^{-}}$ mediated cAMP accumulation by $\sim 48 \%(n=6$; $p<0.05)$, whereas $\mathrm{D} 1 / \mathrm{D} 5_{\mathrm{CT}}$ failed to establish functional interactions with NMDA receptors. These data suggest that the CT of the D1 re- antibody. After treatment for $30 \mathrm{sec}$ with $500 \mu \mathrm{M}$ NMDA/10 $\mu \mathrm{M}$ glycine or ECS, the cells then were labeled with the same primary antibody and a Cy3-conjugated secondary antibody to label the newly inserted membrane HA-D1 receptors. To determine whether the insertion of HA-D1 receptors occurred at the plasma membrane, we subsequently stained cells, under cell-permeabilized conditions, with anti-HLA that predominantly will recognize a monomorphic epitope on the $\alpha$-chain polypeptide of hu- 
man class 1 HLA molecules present at the cell surface (Schreiber et al., 1984). The lack of $\mathrm{Cy} 3$ immunofluorescence in control cells confirmed the complete blockade of preexisting HA-D1 receptors at the plasma membrane by the unconjugated secondary antibody. However, NMDA pretreatment significantly increased the intensity and number of HA-D1 receptor clusters at the cell surface, as shown in Figure $3 A$, left panels. Consistent with the cAMP assay data presented in Figure $2 B$, NMDA-induced enhancement of HA-D1 receptor membrane insertion also could be blocked by the overexpression of the D1-t2 mini-gene (Fig. $3 A$, middle panels), but not with the D1-t 3 mini-gene (Fig. $3 A$, right panels). We further quantified this NMDA-induced increase in HA-D1 receptor membrane insertion by using a cellELISA assay (Lee et al., 2002). Analogous to the immunofluorescent staining results, the ELISA assay revealed a $\sim 25 \%$ increase in HA-D1 receptor on the cell surface by NMDA receptor activation $(n=12 ; p<$ 0.01 ). Furthermore, this process also could be blocked by pretreatment with MK-801 or by the overexpression of the D1- $t 2$, but not D1-t3, mini-genes, indicating the absolute requirement of the $\mathrm{Ca}^{2+}$ influx and that the enhanced D1-mediated cAMP accumulation may be a result of the increased D1 receptor on the cell surface. Moreover, NMDA-induced enhancement of $\mathrm{D} 1$ receptor on the cell surface was blocked at $4^{\circ} \mathrm{C}$ (Fig. $3 B$ ), which is consistent with previous reports that endocytosis/exocytosis is blocked at $4^{\circ} \mathrm{C}$ (Man et al., 2000).

\section{The enhancement of D1-mediated cAMP accumulation and membrane expression depends on membrane fusion exocytosis}

Previous studies have shown that Clostridium tetanus toxin (TeTx) selectively cleaves vesicle-associated membrane protein (VAMP) and prevents exocytosis (Maletic-Savatic and Malinow, 1998; Hua and Charlton, 1999). To test whether the D1 receptor enhancement of the response to NMDA could be produced by insertion of new receptors into the plasma membrane from the intracellular vesicular pool, we repeated the experiments after impairing the fusion of intracellular vesicles with the plasma membrane by using TeTx. We first confirmed that pretreatment with TeTx (100 ng/ $\mathrm{ml}$ ) for $48 \mathrm{hr}$ cleaved the v-SNARE synaptobrevin/VAMP2 in neurons. In cultured neurons significant VAMP2 cleavage occurred on preincubation with TeTx, as illustrated by the lack of an anti-VAMP2 immunoreactive band comparable to a band seen in nontreated neurons, as shown in Figure 3C. Under the same TeTx pretreatment condition the enhancement of D1 receptor membrane expression by the activation of NMDA receptors was prevented completely (Fig. 3B). Similarly, the elimination of VAMP2 also blocked the observed enhancement of D1-mediated

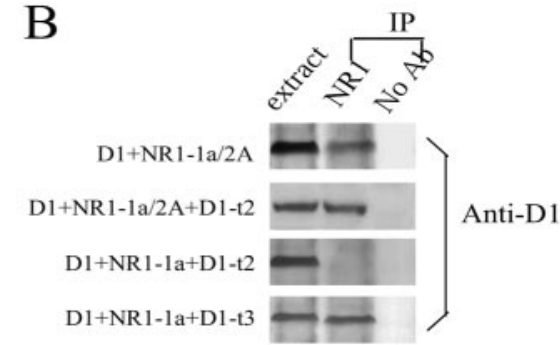

D
Anti-D1

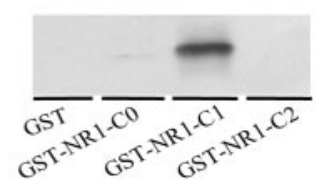

S938

$\mathrm{F}$

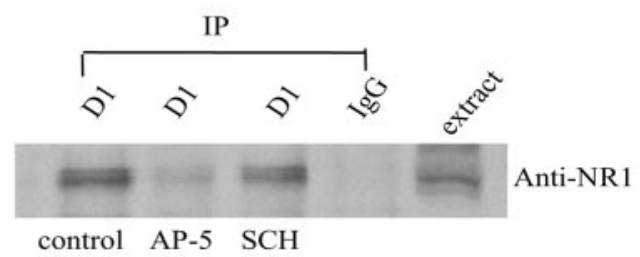

$\left[{ }^{35} \mathrm{~S}\right]-\mathrm{NR}-\mathrm{C} 2$

control AP-5 SCH

Figure 4. Association of dopamine D1 and NMDA receptors. A, Coimmunoprecipitation of D1 receptors, but not D5 receptors, by NR1 antibody in rat hippocampal tissue. $B$, Blockade of the coimmunoprecipitation of D1 receptors by NR1 antibody with the overexpression of the D1-t2 mini-gene, but not the D1-t3 mini-gene, in COS-7 cells coexpressing D1 and NR1-1a subunit, but not NR1-C0, NR1-C1, and NR1-C2. D, Western blots of D1 receptors after affinity precipitation by GST-NR1-C1, but not by GST-NR1-C0, 政 NR1-C0, NR1-C1, or NR1-C2 in vitro-translated peptide, respectively. Then the beads were washed six times with PBS containing 0.5\% Triton X-100 and eluted with $10 \mathrm{~mm}$ glutathione elution buffer. Eluates were separated by SDS-PAGE and visualized by autoradiography. Data are representative of three independent experiments. F, Blockade of the coimmunoprecipitation of NR1 by D1 antibody in cotransfected COS-7 cells pretreated with AP-5, but not with SCH-23390.

cAMP accumulation with NMDA stimulation (Fig. 3D). These data suggest that activation of NMDA receptors modulates D1 receptor function via a membrane fusion-dependent exocytotic process.

NMDA receptor NR1 subunit directly couples to dopamine D1 receptors through the $\mathrm{C} 1$ region of the carboxyl tail

We have shown previously that two regions (D1-t2, D1-t3) in the D1 receptor carboxyl tail can couple directly and selectively to the NMDA glutamate receptor subunits NR1-1a and NR2A (Lee et al., 2002). The observed D1-NMDA protein-protein interactions enable dopamine regulation of NMDA receptor-mediated functions. The fact that NMDA receptor modulation of D1mediated cAMP accumulation and D1 receptor membrane expression could be abolished by the overexpression of D1- $t 2$ mini gene, as presented in Figures $2 B$ and $3 B$, suggests that the D1NMDA protein-protein interaction also may be responsible for the observed NMDA receptor functional modulation of D1 receptors. However, it is unknown which specific region in the 


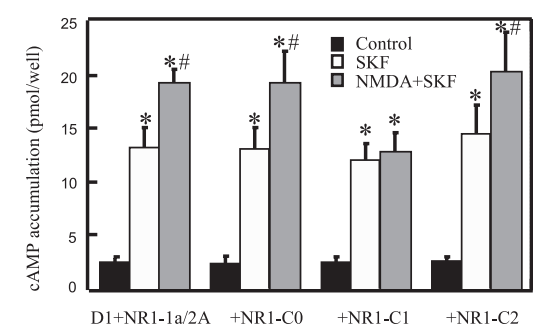

B

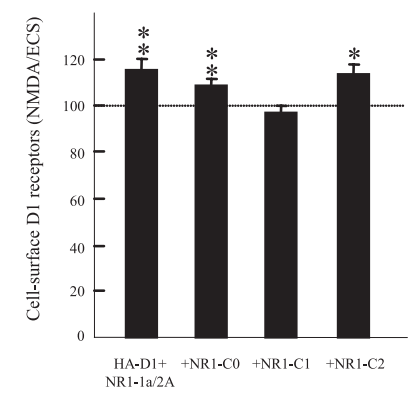

$\mathrm{C}$

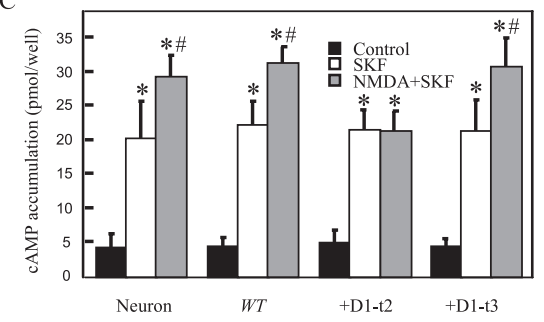

$\mathrm{D}$

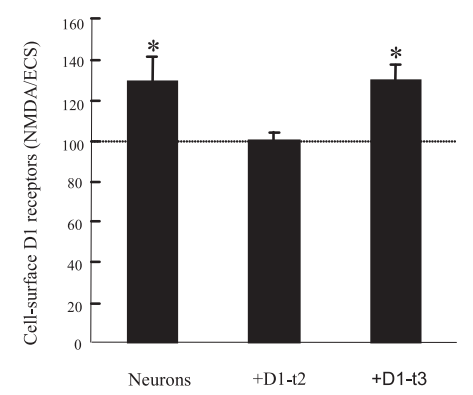

Figure 5. A, In COS-7 cells expressing both D1 and NMDA receptors, the ability of the NMDA receptors to enhance D1 receptormediated CAMP accumulation functionally was abolished by coexpression with a mini-gene encoding the NR1-C1 domain, but not the NR1-C0 or NR1-C2 domains. Statistics analysis was performed by ANOVA, followed by post hoc Student-Newman-Keuls test. ${ }^{*}$ Significantly different from control group ( $p<0.05 ; n=6$ ); ${ }^{*}$ significantly different from SKF treatment group ( $p<0.05 ; n=$ 6). $B$, Summarized data indicating effects of NMDA stimulation on HA-D1 membrane expression in D1/NMDA receptor cotransfected HEK-293 cells with the overexpression of NR1-C0, NR1-C1, or NR1-C2 mini-gene, respectively. Columns show the means \pm SEM of the ratios of colorimetric readings under nonpermeabilized conditions versus permeabilized conditions from cells treated with $500 \mu \mathrm{m} \mathrm{NMDA} / 10 \mu \mathrm{m}$ glycine, normalized to their respective control groups (dashed line) treated with extracellular solution (ECS). ${ }^{*} p<0.05 ;{ }^{* *} p<0.01$ (Student's t test). C, In rat primary cultured neurons the ability of the NMDA receptors to enhance D1 receptor-mediated cAMP accumulation functionally was abolished after infection with the recombinant D1-t2, but not D1-t3, adenovirus. Data were analyzed by ANOVA, followed by post hoc Student-Newman-Keuls test. *Significantly different from control group $(p<0.05 ; n=6)$; ${ }^{\#}$ significantly different from SKF treatment group $(p<0.05 ; n=6)$. D, Summarized data indicating the effects of NMDA stimulation on 11 membrane expression by infecting the cultured hippocampal neurons with the recombinant D1-t2, D1-t3 adenovirus. Columns show the means \pm SEM of the ratios of colorimetric readings under nonpermeabilized conditions versus those under permeabilized conditions from neurons treated with $500 \mu \mathrm{m} \mathrm{NMDA/10} \mu \mathrm{m}$ glycine, normalized to their respective control groups (dashed line) treated with ECS. ${ }^{*} p<0.05$ (Student's $t$ test).

carboxyl tail of the NR1-1a subunit is essential for the direct coupling to D1 receptors. We first confirmed the existence of D1-NMDA receptor complex in rat hippocampal extract. As depicted in Figure 4A, NMDA receptor NR1 subunit antibody can coimmunoprecipitate D1, but not D5, receptors, confirming the specific physical interaction between D1 and NMDA receptors. Given that NMDA receptor modulation of D1mediated cAMP accumulation and D1 receptor membrane expression could be abolished by the overexpression of D1-t2 mini gene as presented in Figures $2 B$ and $3 B$, we examined whether the coimmunoprecipitation of D1 receptors by the NR1 antibody can be blocked by the overexpression of D1-t2 mini-gene. As shown in Figure 4B, overexpression of D1-t2 mini-gene blocked the ability of NR1 antibody to coimmunoprecipitate D1 receptors in the cotransfected D1 and NR1-1a subunit of the cells, but not in cotransfected D1 and NR1$1 \mathrm{a} / 2 \mathrm{~A}$ subunits of the cells because of the coexistence of D1t3-NR2A interaction (Lee et al., 2002). To determine the CT regions of NR1-1a subunit involved in the formation of D1NMDA receptor complex, we constructed various glutathione $S$-transferase (GST) fusion proteins encoding the NR1-C0, $\mathrm{E}_{834}-\mathrm{D}_{864} ; \mathrm{NR} 1-\mathrm{C} 1, \mathrm{D}_{864}-\mathrm{T}_{900}$; and NR1-C2, $\mathrm{T}_{900}-\mathrm{S}_{938}$ (Fig. 4C). As shown in affinity purification assays GST-NR1-C1, but not GST-NR1-C0, GST-NR1-C2, or GST alone, precipitated solubilized D1 receptor, indicating that the NMDA receptor NR1-1a subunit can interact with D1 receptors through its NR1-C1 region of the carboxyl tail (Fig. 4D). In addition, we confirmed that the D1-NR1-1a complex is formed via a direct interaction between D1-t2 and NR1-C1 via in vitro binding assay. GST-D1-t2 and GST-D1-t3 were preincubated with in vitro-translated $\left[{ }^{35} \mathrm{~S}\right]$ methionine-labeled peptides encoding NR1-C0 ([ $\left.\left.{ }^{35} \mathrm{~S}\right]-\mathrm{NR} 1-\mathrm{C} 0\right), \quad \mathrm{NR} 1-\mathrm{C} 1$ $\left(\left[{ }^{35} \mathrm{~S}\right]-\mathrm{NR} 1-\mathrm{C} 1\right)$, or NR1-C2 $\left(\left[{ }^{35} \mathrm{~S}\right]-\right.$ NR1-C2) sequences. As shown in Figure $4 E$, the $\left[{ }^{35} \mathrm{~S}\right]-\mathrm{NR} 1-\mathrm{C} 1$ probe bound with GST-D1-t2, but not with GST-D1-t3 or GST. The binding of $\left[{ }^{35} \mathrm{~S}\right]-\mathrm{NR} 1-\mathrm{C} 1$ with GST-D1-t2 was specific, because GSTD1-t2 did not bind with $\left[{ }^{35} \mathrm{~S}\right]-\mathrm{NR} 1-\mathrm{C} 0$ or $\left[{ }^{35} \mathrm{~S}\right]-\mathrm{NR} 1-\mathrm{C} 2$. Therefore, it appears that the D1-t2 region of the D1 receptor carboxyl tail and $\mathrm{C} 1$ region of the NMDA receptor NR1-1a subunit are responsible for mediating the direct interaction between D1 receptor and NR1-1a subunit of NMDA receptors. Given the fact that the observed D1t2: NR1-C1 may be responsible for the NMDA modulation of D1 receptor function, we tested whether the activation of NMDA receptors affects the observed protein-protein interactions. As shown in Figure $4 F, \mathrm{D} 1$ receptor antibody failed to coimmunoprecipitate NMDA receptors in cotransfected cells pretreated with NMDAspecific antagonist AP-5, but not with D1 receptor-selective antagonist SCH-23390, suggesting that NMDA receptor stimulation, but not D1 receptor activation, is essential to form D1 and NMDA receptor complexes. However, in rat tissue and cotransfected cells, D1 and NMDA receptors could associate without exogenous NMDA receptor agonist stimulation. It is possible that constitutive NMDA receptor activation may occur because of glutamate found in the growth media (Garcia-Gallo et al., 1999).

NMDA modulates D1-mediated cAMP accumulation and D1 receptor membrane expression via D1-t2: NR1-C1 interaction in both cotransfected cells and neurons

Although we have shown a direct interaction between NR1-C1 of the NR1-1a subunit and the D1-t2 of the D1 receptors, there was no direct evidence that NR1-C1 is responsible for the observed NMDA receptor modulation of D1-mediated functions. To identify whether NR1-C1 is involved directly in the functional modulation of D1 receptors, we used NR1-C0, NR1-C1, and NR1-C2 mini-genes in coexpression experiments. As shown in Figure $5 A$, the ability of the NMDA receptor to enhance D1mediated cAMP accumulation could be blocked by the coexpression of NR1-C1, but not NR1-C0 or NR1-C2, mini-gene in COS-7 cells cotransfected with D1 and NR1-1a/2A subunits. Similarly, NMDA receptors failed to modulate $\mathrm{D} 1$ receptor membrane expression in HEK-293 cells overexpressing the NR1-C1 mini-gene with D1 and NMDA receptors (Fig. 5B). Together with the data showing that D1-t2 mini-gene was able to block the NMDA receptor modulation of D1-mediated cAMP accumulation and D1 receptor membrane expression presented in Figures $2 B$ and $3 B$, we conclude that direct coupling between D1-t2 and 
NR1-C1 enables NMDA receptors to modulate functionally the D1-mediated cAMP accumulation and HA-D1 receptor membrane expression. In addition, we used primary rat hippocampal neurons to confirm that the modulation of $\mathrm{D} 1$ receptormediated function by the NMDA receptor occurs in a more physiologically relevant system. In cultured hippocampal neurons NMDA pretreatment significantly increased D1-like receptormediated cAMP accumulation (Fig. 5C) and D1 receptor membrane expression (Fig. 5D). Although SKF-81297 activates both D1 and D5 receptors, it is likely that the increased cAMP accumulation by NMDA is mediated by the D1 receptor because NMDA failed to modulate D5-mediated cAMP accumulation (Fig. 1A). Furthermore, adenoviral-mediated expression of D1-t2 mini gene, but not D1-t3 mini gene, was able to block effectively the NMDA receptor-mediated enhancement of D1 receptor CAMP responsiveness and D1 receptor membrane expression in cultured hippocampal neurons (Fig. 5C,D).

\section{Discussion}

In summary, we provide evidence in both cotransfected cells and cultured hippocampal neurons that activation of NMDA receptors enhances dopamine D1 receptor-mediated cAMP accumulation by recruiting more $\mathrm{D} 1$ receptors to the plasma membrane. Furthermore, the observed NMDA modulation of D1-mediated function is regulated by the direct protein-protein interaction between the D1-t2 region of the carboxyl tail of the D1 receptors and the $\mathrm{C} 1$ region of the NR1-1a subunit, because overexpression of D1-t2 or NR1-C1 mini-gene significantly blocked NMDA receptor enhancement of D1 receptor-mediated function and D1 receptor membrane expression. Several proteins have been shown to bind the $\mathrm{C} 1$ cassette of the NR1 receptor, including calmodulin, actinin (Ehlers et al., 1996; Wyszynski et al., 1997, 1998), yotiao (Lin et al., 1998), and neurofilament-L (Ehlers et al., 1998); these remain as candidates for playing a role in the regulation of NMDA receptor function. In addition, the $\mathrm{C} 1$ cassette of the NR1 subunit also contains an endoplasmic reticulum (ER) retention motif (Standley et al., 2000), and the masking/unmasking of this motif may be critical in the subcellular localization of the NMDA receptor.

NMDA receptor stimulation enhances dopamine D1 receptor-mediated cAMP accumulation in both cotransfected cells and primary hippocampal cultures. We conclude that NMDA-mediated functional modulation of D1 receptordependent CAMP accumulation is not a product of altered pharmacological properties, based on the observations that, in cotransfected COS-7 cells, activation of NMDA receptors did not alter (1) the estimated $\mathrm{EC}_{50}$ for SKF-stimulated D1-mediated cAMP accumulation (Fig. $1 B$ ), (2) the estimated inhibitory constant $\left(K_{\mathrm{i}}\right)$ for SKF from $\left[{ }^{3} \mathrm{H}\right] \mathrm{SCH}-23390$ competition binding assays (Fig. $1 C$ ), or (3) the estimated dissociation constant $\left(K_{\mathrm{D}}\right)$ and the maximal $\left[{ }^{3} \mathrm{H}\right] \mathrm{SCH}-23390$ binding $\left(B_{\max }\right)$ to the D1 receptor (Fig. 1D). Previous studies have shown that both dopamine D1 and D5 receptors specifically couple to Gs protein to stimulate CAMP accumulation and that they share a high degree of amino acid homology (Sunahara et al., 1990, 1991). It is difficult to differentiate D1 and D5 receptors functionally because they exhibit almost identical pharmacological profiles. However, dopamine D5, but not D1, receptors exhibit functional cross-talk with $\mathrm{GABA}_{\mathrm{A}}$ receptors via a direct protein-protein interaction between the carboxyl tail of D5 receptor and the second intracellular loop of the $\gamma 2$ subunit of the $\mathrm{GABA}_{\mathrm{A}}$ receptors (Liu et al., 2000). In addition, we have reported recently that dopamine D1 receptors, but not D5 receptors, can modulate NMDA receptor currents via direct coupling between the D1-t3 region (S417T446) of the carboxyl tail of the D1 receptor and NR2A subunit. In each case the receptor cross-talk is independent of classical G-protein signaling and is facilitated by interactions with specific sequence motifs that do not share homology between D1 and D5 receptors. The direct protein-protein interactions enable functional differentiation of dopamine D1 and D5 receptors and may provide an additional signal transduction pathway for neurotransmitter receptors to exert their physiological functions.

Many receptor/ion channels are trafficked between the plasma membrane and the intracellular compartments via vesicle-mediated membrane insertion and internalization. Regulation of neurotransmitter receptor membrane insertion/internalization has been proven to be an important means of controlling the functions of many receptors, such as opioid receptors (Chu et al., 1997), the $\beta$-adrenergic receptors (Karoor et al., 1998), and AMPA receptors (Man et al., 2000). Generally, agonist stimulation of G-protein-coupled receptors leads to the internalization of the activated receptor. To date, there has been little evidence showing the recruitment of G-protein-coupled receptors to the cell surface with agonist stimulation. Recently, Dr. Aperia's group has shown that in primary cultures of rat neostriatal neurons the activation of NMDA receptors recruits D1 receptors from the interior of the cell to the plasma membrane and thus increases D1-like receptor-mediated cAMP accumulation (Scott et al., 2002). However, the molecular mechanism through which activation of NMDA regulates D1 receptor trafficking and D1-mediated cAMP accumulation is not identified. In contrast, Fiorentini et al. (2003) shows that coexpression of D1 and NR1/2B subunits abolished the agonist-induced D1 receptor intracellular sequestration, suggesting that NMDA receptors may modulate D1 receptor trafficking through multiple regulatory pathways dependent on the NMDA receptor subunit composition, which is consistent with previous reports that clearly have demonstrated functional differences with distinct NMDA receptor subunit compositions (Brimecombe et al., 1997; Vicini et al., 1998; Barria and Malinow, 2002). Although the study by Fiorentini et al. (2003) has similarities to our study reported here, there are still some clear discrepancies. As opposed to what Fiorentini and colleagues have reported, we have shown that NMDA activation not only promotes a recruitment of D1 receptors to the cell surface but that NMDA activation appears to increase the ability of these two receptors to form a complex (Fig. $4 F$ ). More importantly, our study examined the functional consequence of the recruitment of $\mathrm{D} 1$ receptors to the cell surface that are mediated by D1-NMDA direct protein-protein interaction. We speculate that this discrepancy in agonist dependence may be attributable to subunit differences. Whereas Fiorentini and colleagues use NR2B in their studies, we have used NR2A subunits in our experiments. Several studies have demonstrated differential functional NMDA receptor properties dependent on NR2 subunit subtype composition (Krupp et al., 1996; Brimecombe et al., 1997; Sprengel et al., 1998).

In our study the activation of NMDA receptors, for as short as $30 \mathrm{sec}$, can promote membrane expression of dopamine D1 receptors, thereby increasing the availability of D1 receptors for agonist-mediated activation of adenylate cyclase. Furthermore, because the D1-mediated increase in cAMP levels with activation of NMDA receptors is a result of a $30 \mathrm{sec}$ pretreatment of NMDA, the effect is unlikely to be the consequence of increased D1 receptor synthesis. In addition, $\left[{ }^{3} \mathrm{H}\right] \mathrm{SCH}-23390$ saturation ligand-binding analysis on COS-7 homogenates, as opposed to intact whole-cell preparations, exhibits equivalent 
D1 receptor densities, as shown in Figure $1 D$, irrespective of NMDA receptor activation, indicating that the total number of D1 receptors, localized intracellularly and on the cell surface, is not affected with the activation of NMDA receptors. Taken together, we speculate that the increased D1 receptor membrane expression may be attributable to increased membrane insertion from the available intracellular pool of receptors, as indicated in Figure 3. We also have shown that the increased D1 receptor membrane expression is dependent on the direct protein-protein interaction between D1-t2 and NR1-C1. The NMDA receptor activation may promote the D1-NMDA receptor interaction and thereby recruit D1 receptors to the cell surface. In addition, given that there are many reports of the functional modulation of NMDA receptors by D1 receptors through a PKA-dependent pathway (Greengard, 2001), NMDA-mediated increases in D1 receptors at the cell surface via the direct protein-protein interaction may provide a mechanism for the NMDA receptor to modulate/amplify its own signaling.

Many studies have suggested the involvement of dopamine D1-like receptors in the process of working and memory (Sawaguchi and Goldman-Rakic, 1991; Williams and GoldmanRakic, 1995). The fact that D1-like receptor stimulation can alleviate some of the "negative" symptomology of schizophrenia (Davidson and Harvey, 1990; Lidow et al., 1998) and reverse antipsychotic-induced working memory deficits (Castner et al., 2000) indicated the potential role of D1-like receptors in the maintenance and expression of schizophrenia. Furthermore, cortical glutamatergic activity also has been postulated to play a key role in the pathophysiology of schizophrenia (Iversen, 1995; Olney and Farber, 1995; Thornberg and Saklad, 1996; Tamminga, 1998; Dean et al., 1999; Mohn et al., 1999). Reductions of NMDA receptor neurotransmission in the prefrontal cortex mimic most of the behavioral symptomology associated with cognitive deficits in schizophrenia (Jentsch et al., 1997). Postmortem studies have identified a relative decrease of the NR1 subunit in the hippocampus of schizophrenia brains (Gao et al., 2000). In therapeutic trials the agents that enhance NMDA receptor activity have improved selectively the persistent negative symptoms in schizophrenia patients (Goff and Coyle, 2001; Javitt, 2001). Furthermore, NMDA blocking agents such as phencyclidine induce a cluster of symptoms that is often indistinguishable from schizophrenia (Carlsson et al., 2001). These data strongly suggest that both D1-like and NMDA receptor-mediated neurotransmissions are perturbed in a number of cortical areas of the schizophrenia brain. Our data have shown that activation of NMDA receptors not only enables NMDA receptors to form a complex with D1 receptors but also enhances D1-mediated functions via the D1-t2: NR1-C1 direct interaction. Therefore, the hypodopaminergic states may explain why blocking NMDA activity by phencyclidine is able to induce schizophrenia-like symptoms and the reduced NR1 subunit expression is observed in postmortem schizophrenia brain, which is consistent with the fact that clinical agents enhancing NMDA receptor activity will lead to the improvement of negative symptoms of schizophrenia. Thus further research into D1-NMDA interactions may help us in the identification of novel targets for development of new therapeutic agents for schizophrenia.

\section{References}

Barria A, Malinow R (2002) Subunit-specific NMDA receptor trafficking to synapses. Neuron 35:345-353.

Brimecombe JC, Boeckman FA, Aizenman E (1997) Functional conse- quences of NR2 subunit composition in single recombinant $N$-methyl-Daspartate receptors. Proc Natl Acad Sci USA 94:11019-11024.

Carlsson A, Waters N, Holm-Waters S, Tedroff J, Nilsson M, Carlsson ML (2001) Interactions between monoamines, glutamate, and GABA in schizophrenia: new evidence. Annu Rev Pharmacol Toxicol 41:237-260.

Castner SA, Williams GV, Goldman-Rakic PS (2000) Reversal of antipsychotic-induced working memory deficits by short-term dopamine D1 receptor stimulation. Science 287:2020-2022.

Cepeda C, Radisavljevic Z, Peacock W, Levine MS, Buchwald NA (1992) Differential modulation by dopamine of responses evoked by excitatory amino acids in human cortex. Synapse 11:330-341.

Chu P, Murray S, Lissin D, von Zastrow M (1997) Delta and kappa opioid receptors are differentially regulated by dynamin-dependent endocytosis when activated by the same alkaloid agonist. J Biol Chem 272:27124-27130.

Claing A, Laporte SA, Caron MG, Lefkowitz RJ (2002) Endocytosis of G-protein-coupled receptors: roles of G-protein-coupled receptor kinases and $\beta$-arrestin proteins. Prog Neurobiol 66:61-79.

Colwell CS, Levine MS (1995) Excitatory synaptic transmission in neostriatal neurons: regulation by cyclic AMP-dependent mechanisms. J Neurosci 15(Pt 1):1704-1713.

Davidson M, Harvey PD, Bergman RL, Powchik P, Kaminsky R, Losonczy MF, Davis KL (1990) Effects of D1 agonist SKF-38393 combined with haloperidol in schizophrenic patients Arch Gen Psychiatry 47:190-191.

Dean B, Scarr E, Bradbury R, Copolov D (1999) Decreased hippocampal NMDA receptors in schizophrenia. Synapse 32:67-69.

Demchyshyn LL, McConkey F, Niznik HB (2000) Dopamine D5 receptor agonist high affinity and constitutive activity profile conferred by carboxyl-terminal tail sequence. J Biol Chem 275:23446-23455.

Durand GM, Gregor P, Zheng X, Bennett MV, Uhl GR, Zukin RS (1992) Cloning of an apparent splice variant of the rat $N$-methyl-D-aspartate receptor NMDAR1 with altered sensitivity to polyamines and activators of protein kinase C. Proc Natl Acad Sci USA 89:9359-9363.

Ehlers MD, Zhang S, Bernhadt JP, Huganir RL (1996) Inactivation of NMDA receptors by direct interaction of calmodulin with the NR1 subunit. Cell 84:745-755.

Ehlers MD, Fung ET, O’Brien RJ, Huganir RL (1998) Splice variant-specific interaction of the NMDA receptor subunit NR1 with neuronal intermediate filaments. J Neurosci 18:720-730.

Fiorentini C, Gardoni F, Spano P, Luca MD, Missale C (2003) Regulation of dopamine D1 receptor trafficking and desensitization by oligomerization with glutamate $N$-methyl-D-aspartate receptors. J Biol Chem 278:20196-20202.

Gao XM, Sakai K, Roberts R, Conley RR, Dean B, Tamminga CA (2000) Ionotropic glutamate receptors and expression of $N$-methyl-D-aspartate receptor subunits in subregions of human hippocampus: effects of schizophrenia. Am J Psychiatry 157:1141-1149.

Garcia-Gallo M, Behrens MM, Renart J, Diaz-Guerra M (1999) Expression of $N$-methyl-D-aspartate receptors using vaccinia virus causes excitotoxic death in human kidney cells. J Cell Biochem 72:135-144.

Goff DC, Coyle JT (2001) The emerging role of glutamate in the pathophysiology and treatment of schizophrenia. Am J Psychiatry 158:1367-1377.

Goldman-Rakic PS (1999) The relevance of the dopamine-D1 receptor in the cognitive symptoms of schizophrenia. Neuropsychopharmacology 21:S170-S180.

Greengard P (2001) The neurobiology of slow synaptic transmission. Science 297:1024-1030.

Guilarte TR, McGlothan JL (2003) Selective decrease in NR1 subunit splice variant $\mathrm{mRNA}$ in the hippocampus of $\mathrm{Pb}^{2+}$-exposed rats: implications for synaptic targeting and cell surface expression of NMDAR complexes. Brain Res Mol Brain Res 113:37-43.

Hollmann M, Heinemann S (1994) Cloned glutamate receptors. Annu Rev Neurosci 17:31-108.

Hollmann M, Boulter J, Maron C, Beasley L, Sullivan J, Pecht G, Heinemann S (1993) Zinc potentiates agonist-induced currents at certain splice variants of the NMDA receptor. Neuron 10:943-954.

Hua SY, Charlton MP (1999) Activity-dependent changes in partial VAMP complexes during neurotransmitter release. Nat Neurosci 2:1078-1083.

Huang KX, Bergstrom DA, Ruskin DN, Walters JR (1998) N-methyl-Daspartate receptor blockade attenuates D1 dopamine receptor modulation of neuronal activity in rat substantia nigra. Synapse 30:18-29.

Huang YY, Kandel ER (1995) D1/D5 receptor agonists induce a protein 
synthesis-dependent late potentiation in the CA1 region of the hippocampus. Proc Natl Acad Sci USA 92:2446-2450.

Iversen SD (1995) Interactions between excitatory amino acids and dopamine systems in the forebrain: implications for schizophrenia and Parkinson's disease. Behav Pharmacol 6:478-491.

Javitt DC (2001) Management of negative symptoms of schizophrenia. Curr Psychiatry Rep 3:413-417.

Jentsch JD, Redmond DE, Elsworth JD, Taylor JR, Youngren KD, Roth RH (1997) Enduring cognitive deficits and cortical dopamine dysfunction in monkeys after long-term administration of phencyclidine. Science 277:953-955.

Karoor V, Wang L, Wang HY, Malbon CC (1998) Insulin stimulates sequestration of $\beta$-adrenergic receptors and enhanced association of $\beta$-adrenergic receptors with Grb2 via tyrosine 350. J Biol Chem 273:33035-33041.

Keefe KA, Ganguly A (1998) Effects of NMDA receptor antagonists on D1 dopamine receptor-mediated changes in striatal immediate early gene expression: evidence for involvement of pharmacologically distinct NMDA receptors? Dev Neurosci 20:216-228.

Konradi C, Leveque JC, Hyman SE (1996) Amphetamine and dopamineinduced immediate early gene expression in striatal neurons depends on postsynaptic NMDA receptors and calcium. J Neurosci 16:4231-4239.

Krupp JJ, Vissel B, Heinemann SF, Westbrook GL (1996) Calciumdependent inactivation of recombinant $N$-methyl-D-aspartate receptors is NR2 subunit specific. Mol Pharmacol 50:1680-1688.

Lee FJS, Xue S, Pei L, Vukusic B, Nadege C, Wang YS, Wang YT, Niznik HB, Yu XM, Liu F (2002) Dual regulation of NMDA receptor functions by direct protein-protein interactions with the dopamine D1 receptor. Cell 111:219-230.

Lidow MS, Williams GV, Goldman-Rakic PS (1998) The cerebral cortex: a case for a common site of action of anti-psychotics. Trend Pharmacol Sci 19:136-140.

Lin JW, Wyszynski M, Madhavan R, Sealock R, Kim JU, Sheng M (1998) Yotiao, a novel protein of neuromuscular junction and brain that interacts with specific splice variants of NMDA receptor subunit NR1. J Neurosci 18:2017-2027.

Liu F, Yuan Y, Sugamori KS, Hamadanizadeh A, Lee FJS, Pang SF, Brown GM, Pristupa ZB, Niznik HB (1995) Molecular and functional characterization of a partial cDNA encoding a novel chicken brain melatonin receptor. FEBS Lett 374:273-278.

Liu F, Wan Q, Pristupa ZB, Yu XM, Wang YT, Niznik HB (2000) Direct protein-protein coupling enables cross-talk between dopamine D5 and gamma-aminobutyric acid A receptors. Nature 403:274-280.

Lu W, Man H, Ju W, Trimble WS, MacDonald JF, Wang YT (2001) Activation of synaptic NMDA receptors induces membrane insertion of new AMPA receptors and LTP in cultured hippocampal neurons. Neuron 29:243-254

Maletic-Savatic M, Malinow R (1998) Calcium-evoked dendritic exocytosis in cultured hippocampal neurons. Part I: trans-Golgi network-derived organelles undergo regulated exocytosis. J Neurosci 18:6803-6813.

Man HY, Lin JW, Ju WH, Ahmadian G, Liu L, Becker LE, Sheng M, Wang YT
(2000) Regulation of AMPA receptor-mediated synaptic transmission by clathrin-dependent receptor internalization. Neuron 25:649-662.

Michaelis EK (1998) Molecular biology of glutamate receptors in the central nervous system and their role in excitotoxicity, oxidative stress, and aging. Prog Neurobiol 54:369-415.

Missale C, Nash SR, Robinson SW, Jaber M, Caron MG (1998) Dopamine receptors: from structure to function. Physiol Rev 78:189-225.

Mohn AR, Gainetdinov RR, Caron MG, Koller B (1999) Mice with reduced NMDA receptor expression display behaviors-related schizophrenia. Cell 98:427-436.

Olney JW, Farber NB (1995) Glutamate receptor dysfunction in schizophrenia. Arch Gen Psychiatry 52:998-1007.

Sawaguchi T, Goldman-Rakic PS (1991) D1 dopamine receptors in prefrontal cortex: involvement in working memory. Science 251:947-950.

Schreiber AB, Schlessinger J, Edidin M (1984) Interaction between major histocompatibility complex antigens and epidermal growth factor receptors on human cells. J Cell Biol 98:725-731.

Scott L, Kruse MS, Forssberg H, Brismar H, Greengard P, Aperia A (2002) Selective up-regulation of dopamine D1 receptors in dendritic spines by NMDA receptor activation. Proc Natl Acad Sci USA 99:1661-1664.

Sprengel R, Suchanek B, Amico C, Brusa R, Burnashev N, Rozov A, Hvalby O, Jensen V, Paulsen O, Andersen P, Kim JJ, Thompson RF, Sun W, Webster LC, Grant SG, Eilers J, Konnerth A, Li J, McNamara JO, Seeburg PH (1998) Importance of the intracellular domain of NR2 subunits for NMDA receptor function in vivo. Cell 92:279-289.

Standley S, Roche KW, McCallum J, Sans N, Wenthold RJ (2000) PDZ domain suppression of an ER retention signal in NMDA receptor NR1 splice variants. Neuron 28:887-898.

Sugihara H, Moriyoshi K, Ishii T, Masu M, Nakanishi S (1992) Structures and properties of seven isoforms of the NMDA receptor generated by alternative splicing. Biochem Biophys Res Commun 185:826-832.

Sunahara RK, Niznik HB, Weiner DM, Stormann TM, Brann MR, Kennedy JL, Gelernter JE, Rozmahel R, Yang YL, Israel Y (1990) Human dopamine D1 receptor encoded by an intronless gene on chromosome 5 . Nature 347:80-83.

Sunahara RK, Guan HC, O’Dowd BF, Seeman P, Laurier LG, Ng G, George SR, Torchia J, Van Tol HH, Niznik HB (1991) Cloning of the gene for a human dopamine D5 receptor with higher affinity for dopamine than D1. Nature 350:614-619.

Tamminga CA (1998) Schizophrenia and glutaminergic transmission. Crit Rev Neurobiol 12:21-36.

Thornberg SA, Saklad SR (1996) A review of NMDA receptors and the phencyclidine model of schizophrenia. Pharmacotherapy 16:82-93.

Vicini S, Wang JF, Li JH, Zhu WJ, Wang YH, Luo JH, Wolfe BB, Grayson DR (1998) Functional and pharmacological differences between recombinant $N$-methyl-D-aspartate receptors. J Neurophysiol 79:555-566.

Williams GV, Goldman-Rakic PS (1995) Modulation of memory fields by dopamine D1 receptors in prefrontal cortex. Nature 376:572-575.

Wyszynski M, Lin J, Rao A, Nigh E, Beggs AH, Craig AM, Sheng M (1997) Competitive binding of $\alpha$-actinin and calmodulin to the NMDA receptor. Nature 385:439-442

Ziff EB (1997) Enlightening the postsynaptic density. Neuron 19:1163-1174. 